\title{
Architectural Notices Relating Chiefly to Ecclesiastical Structures in the County of Gloucester
}

\author{
The Rev. J. L. Petit M.A.
}

To cite this article: The Rev. J. L. Petit M.A. (1849) Architectural Notices Relating Chiefly to Ecclesiastical Structures in the County of Gloucester, Archaeological Journal, 6:1, 40-45, DOI: 10.1080/00665983.1849.10850720

To link to this article: http://dx.doi.org/10.1080/00665983.1849.10850720

Published online: 10 Jul 2014.

Submit your article to this journal ¿ 
ARCHITECTURAL NOTICES RELATING CHIEFLY TO ECCLESIASTICAL STRUCTURES IN THE COUNTY OF GLOUCESTER, BY THE REV.J. L. PETIT, M.A. ${ }^{1}$

IN resuming my architectural notices, it is as well to remind the reader that I do not profess to call his attention to all the remarkable objects of any district from which I may select my specimens. I shall often pass by some building of great beauty and interest, while I take note of a comparatively insignificant one in its immediate neighbourhood. And it may not always be easy to give a reason for my choice, unless it be that the finest specimens are generally pretty well known, and that in the study of those of less note we may occasionally meet with new and characteristic features, and discover combinations interesting both to the antiquary and the practical architect. Many of the more important structures which I have visited would require a much fuller description than is suitable for such a memoir as the present; for instance, the magnificent remains of Pershore Church, of which I shall therefore say nothing beyond remarking that the visitor ought by no means to neglect going up into the story of the tower above the present roof, originally, without doubt, opened as a lantern, which forms a rare and beautiful composition of decorated work.

And again, smaller churches are more liable to the danger of restoration. Many precious objects have been irreparably lost to the antiquary by the zeal of persons who consider the neat and perfect appearance of new work to be more suitable to a church, than the dignity resulting from the gradual impression of ages, and the force of long associations.

About six miles to the north of Cheltenham, near a remarkable eminence distinguished from the rest of the range by its insulated position and a single tree upon its summit, is the village (if the term can be applied to so small a group) of Stanley-Pontlarge. Here we find that combination which is so common in Gloucestershire; viz., the large farm-house, originally perhaps a manor-house of some importance, and

1 We are desirous to express here the cordial acknowledgment of the liberal kindness of Mr. Petit, in addition to many valuable donations of a similar nature on previous ocensions. The whole of the illustrations, accompanying this memoir, have been generously presented by him to the Institute. 


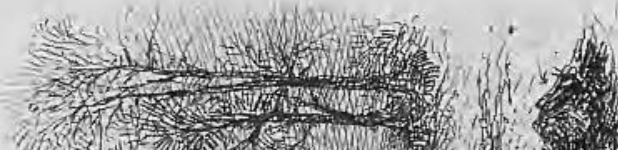

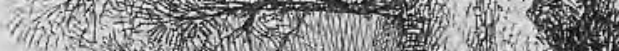

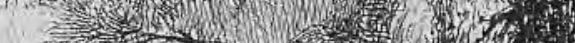

H.

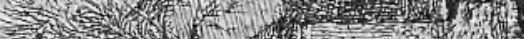

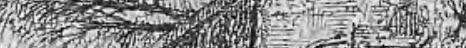

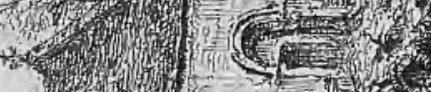

40130 . th 7 (1)

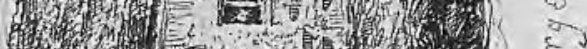

G.

6.7.
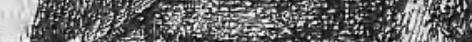
$\varepsilon^{8}$
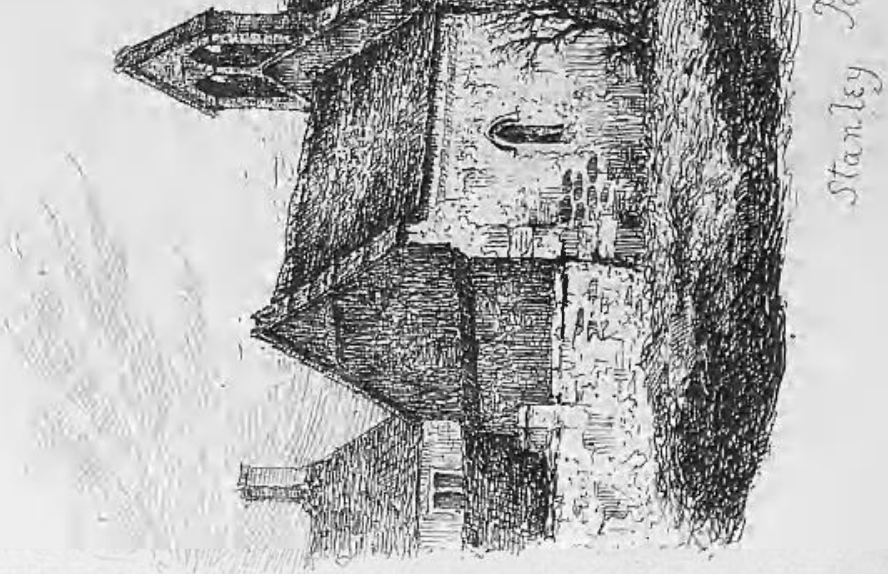


\section{ARCHITECTURAL NOTICES.}

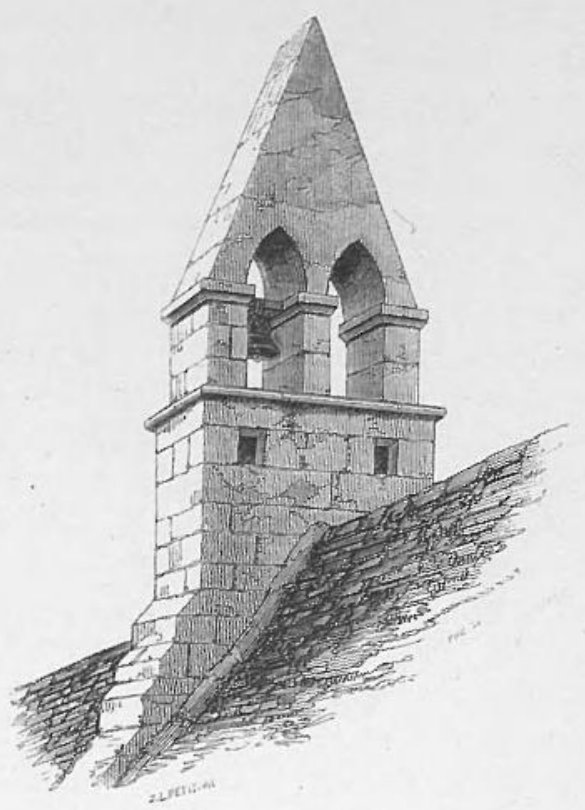

Belfry, Wyre Church, near Pershore.

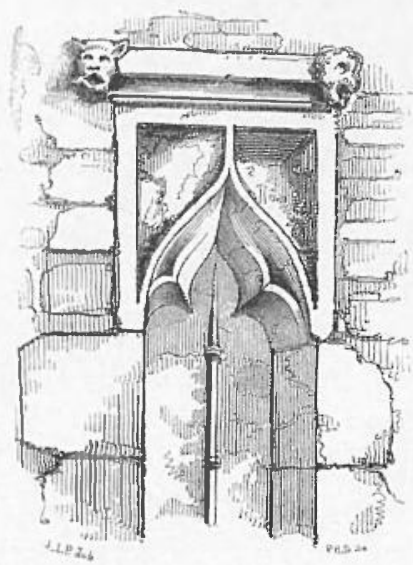

Window, Manor House, Stanley PontJarge 
the chapel adjoining. The first of these has been much rebuilt and modernised, but still contains some medieval work ; of which the most striking specimen is a window of a single light with an ogee trefoiled arch under a square head, having a horizontal label, the corbels of which are heads of animals with open mouths, forming waterspouts. I should say its character is late Decorated, or early Perpendicular. The chapel, situated but a few yards to the north of this, is Norman, with later insertions. It consists of a nave and chancel, and has over the chancel arch a bell-turret of two pointed arches under a gable of good pitch. As such gables are very frequently devoid of any mouldings characteristic of style, the plainness of the present one does not prove it to belong to an early date, though I am much inclined to believe it does so, more especially as one of a similar description on a small church near Pershore has very decidedly early characteristics. The chancel arch at Stanley-Pontlarge is semicircular, of two orders, the inferior, plain without a chamfer ; the superior, with chevrons on the western face, a label, and a shaft at the edge of its impost. The eastern face of the arch is comparatively plain. There is no east window. On the south side of the chancel is a piscina of later date, projecting from the wall, and of the sedilia, a standard or elbow remains, probably one of a pair between which the bench was placed. This is of stone-work. The north and south door of the nave are Norman, the former has a transom with an ornamented border. The arch has two orders, with shafted imposts, and a label. Both the orders have the chevron in the soffit, and the label has billets at a distance from each other. This chapel, though small, is a most picturesque and interesting edifice. The Norman work is good and very pure; I should say of an early date.

At a short distance to the north-west of the chapel is a farm-house in the Tudor style. The south end, which is a gable, has a good chimney, tapering in stages from the ground, and square at the top, where it is finished with a cornice of shallow projection, crowned with a row of small battlements or knobs. The windows have square-headed labels, the lights being arched, scarcely, if at all, pointed, and without foliation. This house, in its present state, is of a simple oblong plan, with a gable at each end.

Near Bishops Cleeve, on the Evesham road, is a farmVOL. vI. 
house, in which some old work yet remains. Here is a very beautiful chimney; whatever may be its date, its character is rather Decorated than Perpendicular. It is octagonal, springing from a rectangular base, and is crowned with an obtuse spire, of which the alternate sides have projecting spire-lights, with open trefoiled arches, the four intermediate sides having open trefoiled arches on the slope. In the shaft, also, below the string under the spire, is an open trefoiled arch on each face. I should think this must be a really good and useful chimney, as well as a very ornamental one.

Among the beautiful remains at Evesham, I will only call attention to another specimen of a chimney, probably of a later date than the last. This also is octagonal, upon a square or rectangular base. Its upper stage rests on a string, and has an open trefoiled arch in each face. The capping is embattled. It belongs to a building engaged in the south wall of the church-yard, which is the old north wall of the abbey.

About four miles from Evesham, to the left of the road leading to Cheltenham, is Sedgeberrow, the church of which deserves attention, both as a beautiful and somewhat unique specimen of old work, and as a very available model in the present day. It is of a simple oblong plan, with no architectural division or distinction between the nave and chancel, except that the windows of the latter, though with the same number of lights, are somewhat narrower. There has been, however, a rood-screen, of which part remains. The belfry is an octagonal turret at the west end, five sides being carried down to the ground, and projecting boldly in the plan. It is divided into four stages by string-courses, and crowned with a spire, of which the angles are ribbed. The windows of the turret are tall square-headed openings. The style of the church is Decorated, apparently late, though the side-windows (of two lights) have tracery of rather a geometrical than flowing character. The east window has five lights, and, although perpendicular lines occur in its tracery, is such as might have been very well constructed at a late period of the Decorated style. The piscina has a handsome crocketted canopy with a projecting ogee, and is supported by an engaged octagonal shaft. The sedilia consist of a stone bench between two projecting elbows. There are a few remains of Decorated glass in situ. The roof is an arched timber one, like the frame-work of a ship ; such is not uncom- 
ARCHITECTURAL NOTICES.

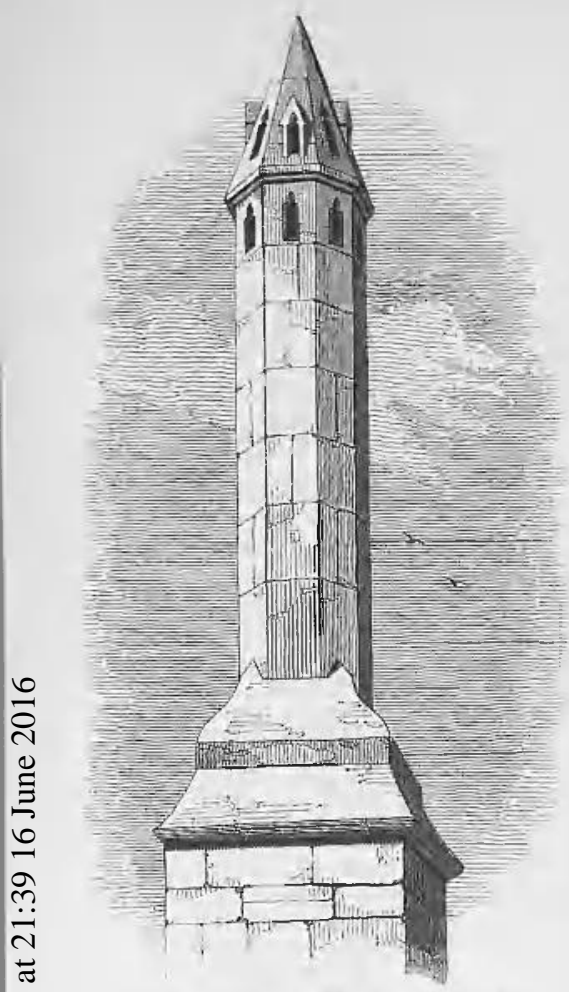

Chimney at Biahop's Cleeve.

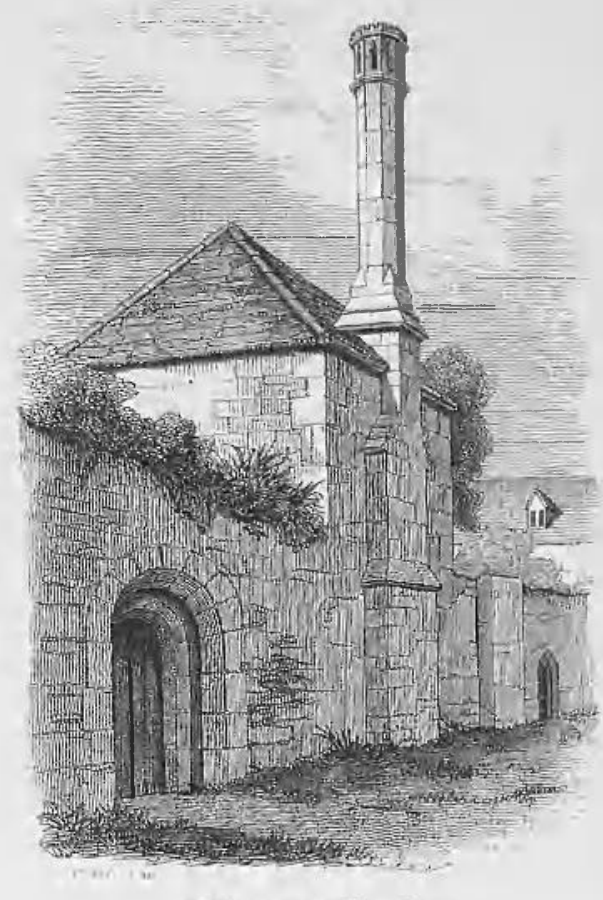

Chimney at Evesintm

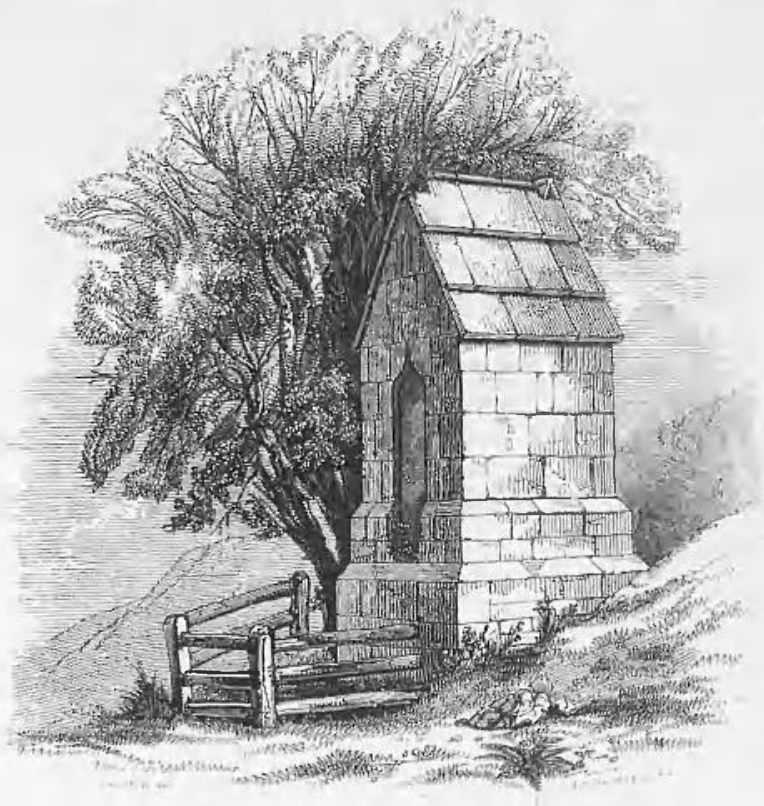

Chapel over Well, near Hempstead. 
ARCHITEC'TURAL NOTICES.

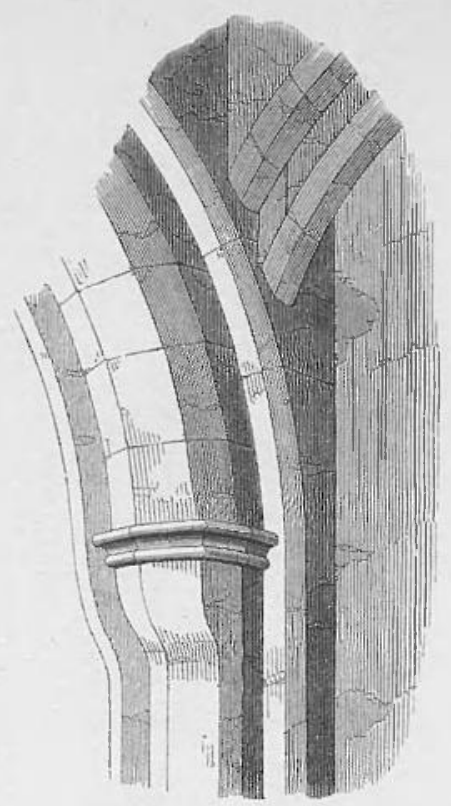

Construction of Tower Arches, Hempstead.

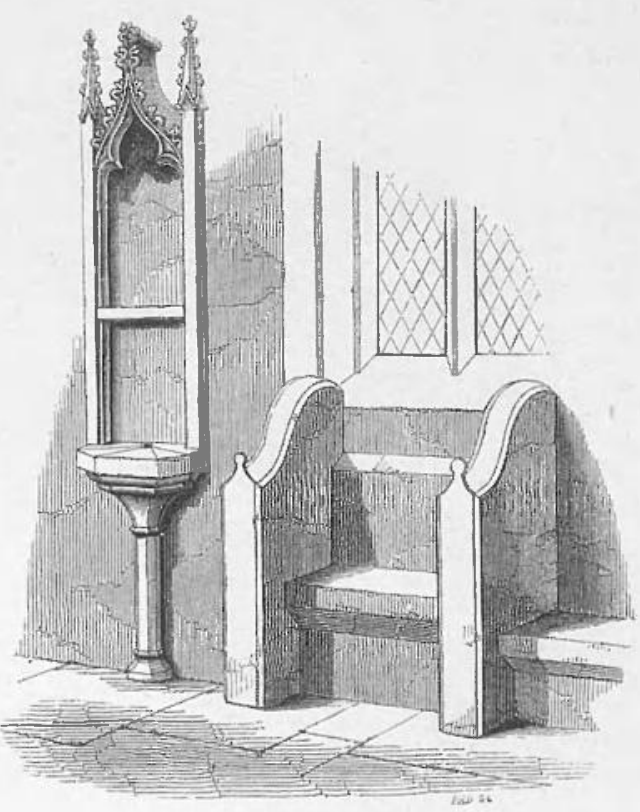

Piscina and Sedilia, Sed̄geberrow. 
ARCHITEC'TURAL NOTIGES.

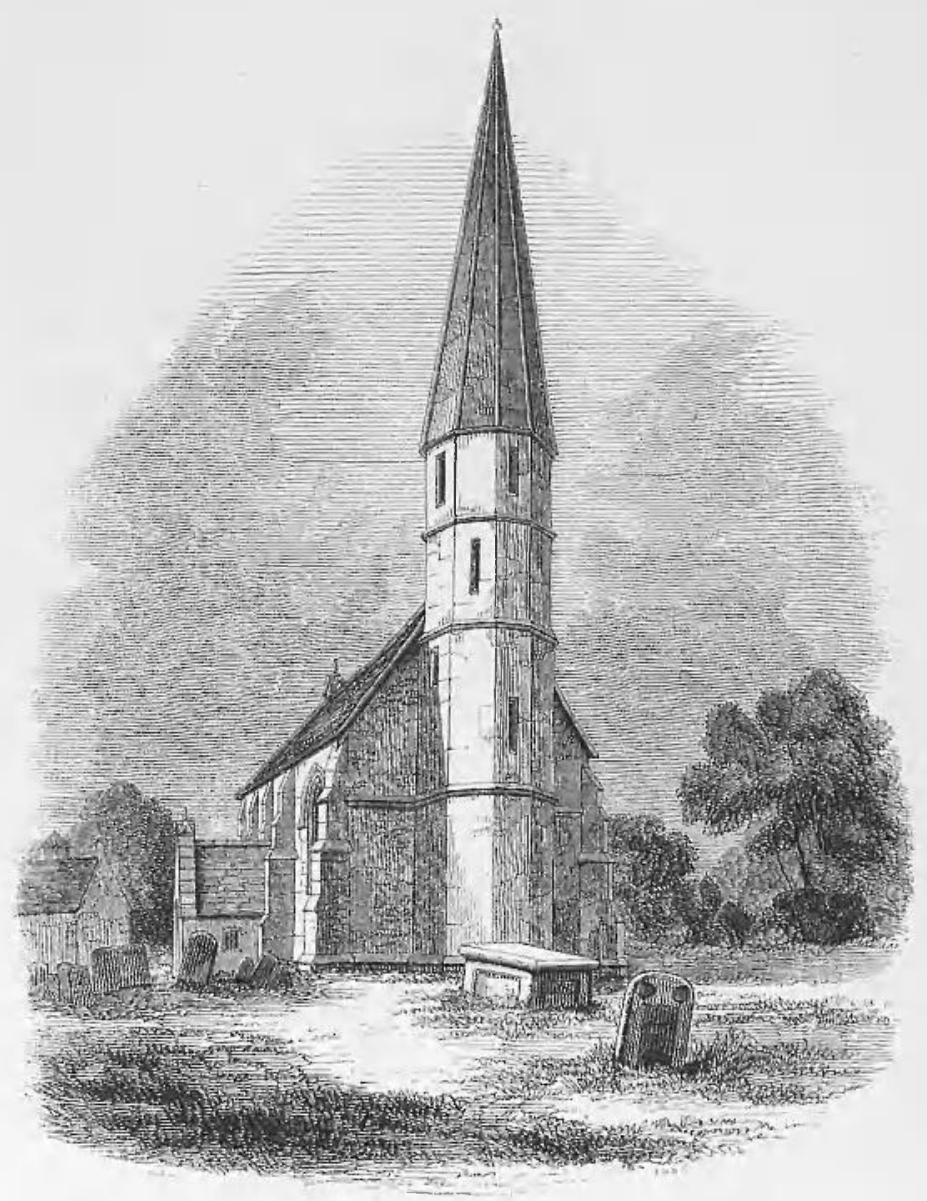

Sedgeberrow Cburch.-- See page 42. 


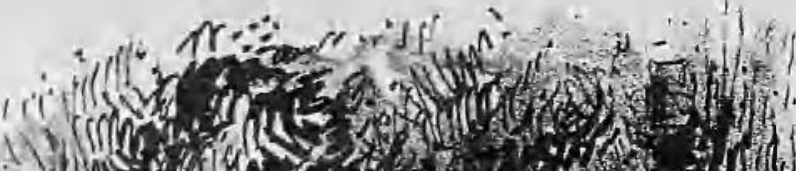

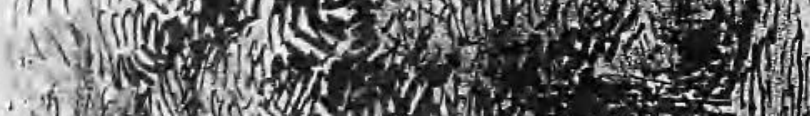

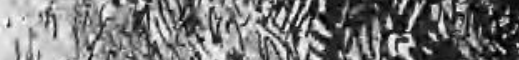

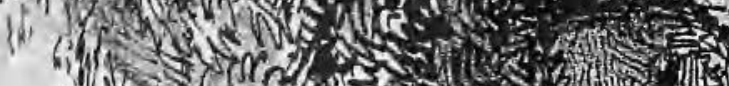

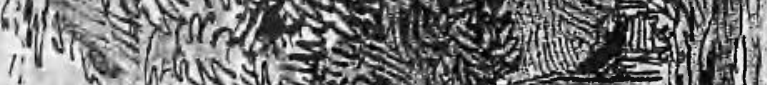

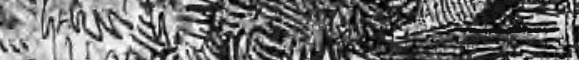

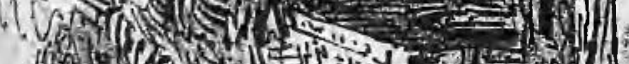

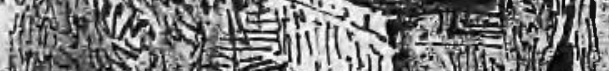

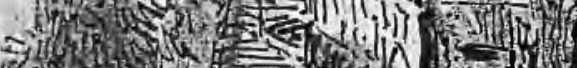
(6) (1)

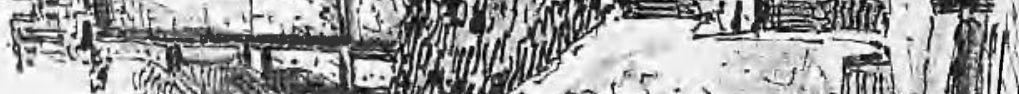

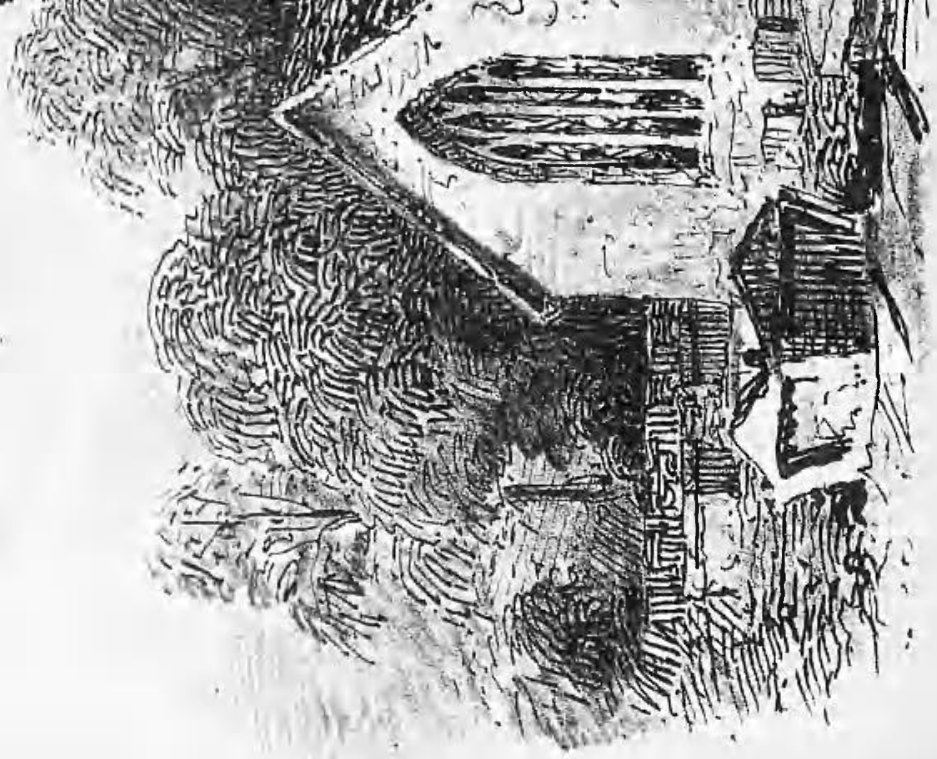


mon in some parts of Gloucestershire ; and there are remains of good wood-work in the pewing. There is a north and south door, the former of which has a porch. The masonry on the whole is good and regular, though, as in many churches in the neighbourhood, the lias of the district is too freely used to be consistent with dryness.

Hempstead Church, near Gloucester, is a picturesque object both in its form and position. But I notice it as furnishing a peculiar example of construction. The tower, which is central, is not so wide as the chancel or nave; but that the imposts of the transverse arches may not project inconveniently into the body of the church, a span is given them nearly corresponding to the full width of the building; the north and south arches, however, supporting the tower, spring from points in the face of the transverse ones considerably above, and overhanging the capitals of the imposts, so that the internal area of the tower falls considerably within the corresponding area on the floor of the church. The weight of the walls above, and the thickness of the transverse arches, form sufficient abutment. The tower is Perpendicular, with rather heavy string-courses and mouldings. The belfry window is large, but the panelling of the embattled parapet, and the projection of the gurgoyles, give it a rich and bold effect. The chancel is chiefly Decorated; the nave appears to have been much modernised.

In crossing the fields between this church and Gloucester, we come upon a relic of rather an uncommon description in this country. It is a small cell or chapel erected over a well, probably belonging to Llantony Abbey, on the south side of Gloucester. The entrance to the building is bricked up, so that it is impossible to say what the interior may be. The plan is nearly a square of seven feet, on a wider basement. The east and west ends are gabled; in the latter is an ogee door, and a narrow ogee window of one light. On the east end is some sculpture, which seems to have been a rood. The covered roof is of stone, and the ridge is finished with a rib. The whole is of good ashlar masonry. This little building stands on the side of rather an abrupt slope, overlooking the valley of the Severn. A fine thorn tree which overhangs it, adds much to its picturesque beauty.

The next object we will consider, though from its retired 
position, it may have attracted little notice, appears to have been a conventual church of some importance. On arriving. at the Frocester station, on the Gloucester and Bristol railroarl, a walk of a mile and a half brings us to Leonard Stanley. The church is in the form of a cross, with a central tower, and no aisles; its style principally Norman, of a pure and early character; with later additions and insertions. The nave has a fine western Norman door, enriched with chevrons both on the face and soffit of the arch, and a billetted label. The side windows are mostly inserted, being Decorated and Perpendicular, though some with semicircular heads still remain. The arches under the tower are semicircular, of two plain orders without any chamfer. The inner is supported by a couplet of large engaged shafts, (a mark of early Norman,) and the imposts of the outer ones have buttresses, whether original, or added for strength. These occur in all the arches. The north transept has a Perpendicular window inserted in its front, but the south transept retains its own Norman one, with a deep splay. The Norman buttresses at the angles of the transepts are also retained. The south transept has a round arch on the east side, as if there had been an apsidal recess, as at Tewkesbury, Gloucester, \&c. The chancel appears to have been constructed for vaulting in two bays on Norman shafts, which still remain, though decorated windows have been inserted both in the sides, and at the east end. The east window retains some painted glass in the tracery lights, one of which has a figure surrounded with quarries. The piscina is a trefoiled opening-near it is an elegant and interesting piece of sculpture, of which a cut is annexed. This is evidently of a Norman period, if not earlier. There seem to be some early English remains in the chancel. The length of the church internally is 131 feet, of which the nave, from the west wall to the west arch of the tower is 73 feet 9 inches. The total width internally, from north to south wall of transepts, is 67 feet 7 inches. The length of the chancel, from the east wall to the eastern arch of the tower, is 32 feet 9 inches. The width of the nave is 23 feet 3 inches; the width of the chancel 20 feet 7 inches. The area of the tower is oblong; its measurement from east to west, including the thickness of the tower arches, being 25 feet 7 inches. From north to south, 33 feet 2 inches. Externally, the tower is low and 


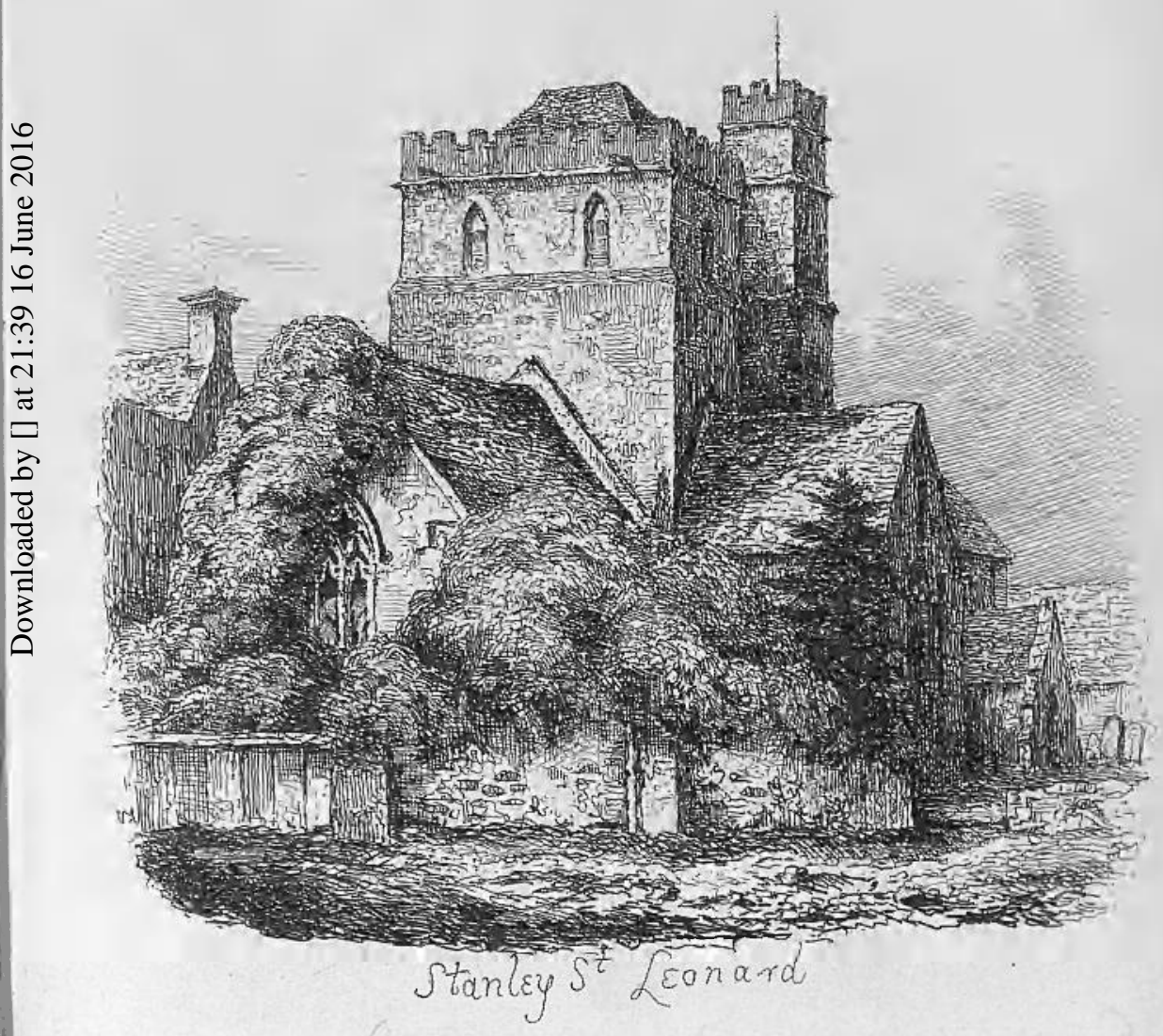


A RCHITECTURAL ROTICES.

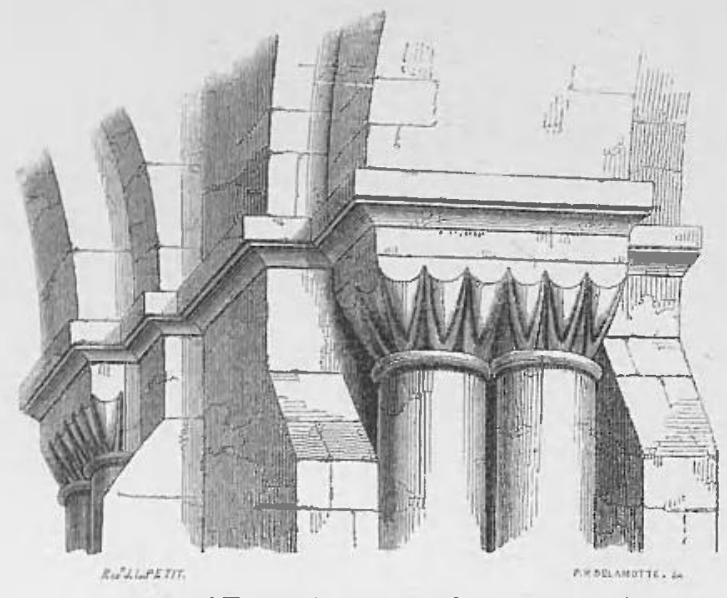

spring of Tower Archee, Stanley St. Leonard.

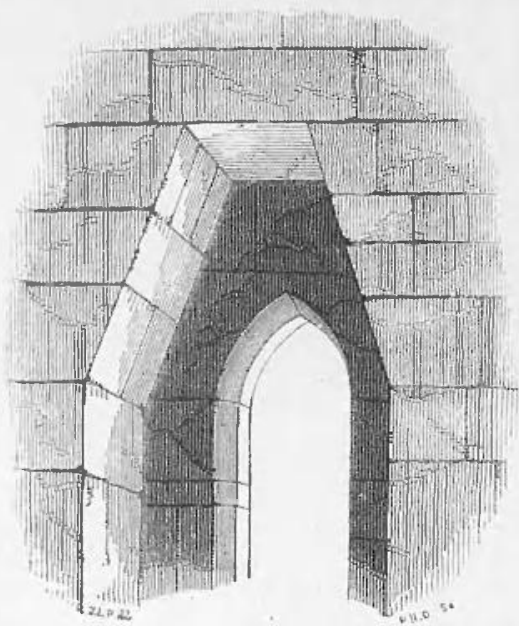

Brilíry Window Interior, Stanley St. Leonard.

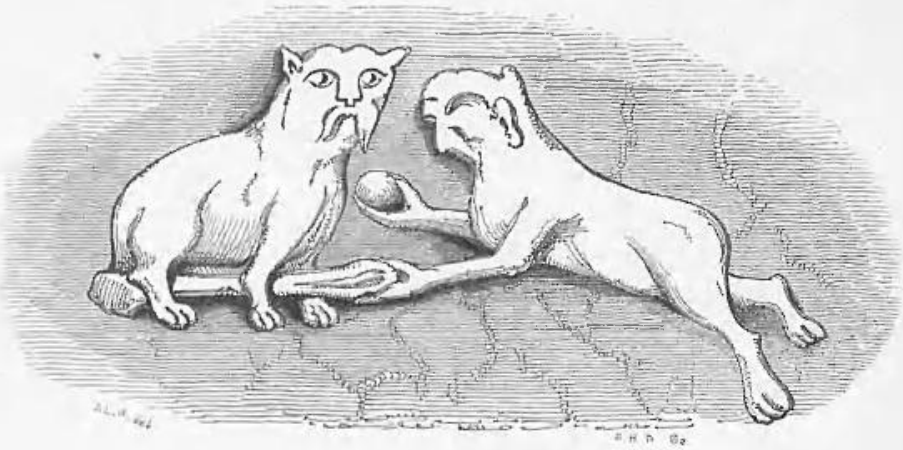

Sculpture in Chancel, Stanley St. Leonard. 
massive; its parapet is embattled ; the belfry windows are plain pointed ones without foliation. There is a bold northwestern turret to the tower, wholly disengaged; that is, its eastern wall being a continuation of the western wall, and its southern of the northern wall, of the tower. This arrangement always gives great effect to the outline, though it involves somewhat narrow passages in obtaining access to the belfry. The porch to the nave is on the north side. There is no chancel door. The orientation is east-south-east magnetically. On the north side of the church-yard is a lichgate; picturesque, but of no special architectural character. On the south side of the church, parallel with the nave, is a barn, (or building now used as such,) with a decorated window of three lights at the east end ; and a little to the south-west, its walls being inclined in a south-westerly direction, is another barn with a decorated window of two lights in its north-east end, and the remains of a good finial on the gable. I had not time to give sufficient attention to these buildings; but the mere mention of them will tend to establish the conventual character of the church. Supposing it to have retained its Norman work unmixed, it perhaps would not have differed very much either in magnitude or general appearance, from the conventual church within the walls of Porchester Castle in Hampshire.

(To be continued.)

I. L. PETIT.

\section{ANCIENT SEPULCHRAL STONE CISTS DISCOVERED IN YORKSHIRE.}

AT the monthly meeting of the Institute in December last, there were exhibited drawings of two remarkable Stone Cists or Coffins, of considerable antiquity, now preserved in the pleasure grounds at Swinton Park, Yorkshire. No. 1 was discovered in the year 1835 by workmen who were digging gravel from an extensive ridge or hill of that material, lying about 200 yards distant from the right bank of the present course of the stream of the river Eure, in the parish of Masham, in the North Riding of Yorkshire. The ridge is raised ten or twelve feet above the level of the adjacent soil, in an extensive open field called the Mar or Mere Field, and is now grown over with brush-wood, forming 